\title{
酸化物超伝導関連物質 $\mathrm{Li}_{x} \mathrm{KCa}_{2} \mathrm{Na}_{2} \mathrm{Nb}_{5} \mathrm{O}_{16}$ の誘導結合 プラズマ発光分光分析のための試料分解法
}

\author{
石 黒 三岐雄 ${ }^{1}$
}

\begin{abstract}
Dissolution method for $\mathrm{Li}_{x} \mathrm{KCa}_{2} \mathrm{Na}_{2} \mathrm{Nb}_{5} \mathrm{O}_{16}$ superconductor compounds in inductively coupled plasma-optical emission spectrometry
\end{abstract}

Mikio ISHIKURO ${ }^{1}$

${ }^{1}$ Institute for Material Research, Tohoku University, 2-1 - 1, Katahira, Aoba-ku, Sendai-shi, Miyagi 980 - 8577

(Received 27 October 2003, Accepted 4 December 2003)

\begin{abstract}
Proper dissolution procedures for perovskite-type niobium oxide compounds were investigated for an elemental determination in inductively coupled plasma-optical emission spectrometry (ICP-OES). Niobium oxide compounds are usually decomposed by using several kinds of fluxes. However, flux compounds, such as sodium disulfate $\left(\mathrm{Na}_{2} \mathrm{~S}_{2} \mathrm{O}_{7}\right)$ and potassium hydrogensulfate $\left(\mathrm{KHSO}_{4}\right)$, are not employed for $\mathrm{Li}_{x} \mathrm{KCa}_{2} \mathrm{Na}_{2} \mathrm{Nb}_{5} \mathrm{O}_{16}$, because these fluxes contain sodium or potassium. This paper describes a new dissolution method with an acid mixture that is suitable for the analysis of $\mathrm{Li}_{x} \mathrm{KCa}_{2} \mathrm{Na}_{2} \mathrm{Nb}_{5} \mathrm{O}_{16}$ samples by ICP-OES. The samples were not decomposed with $\mathrm{H}_{2} \mathrm{SO}_{4}$ only nor with $\mathrm{HF}-\mathrm{HNO}_{3}$. However, they were able to decompose with an acid mixture of $\mathrm{HF}-\mathrm{HNO}_{3}-\mathrm{H}_{2} \mathrm{SO}_{4}$. Also, in a microwave-assisted dissolution method, the samples were completely decomposed only when a ternary acid mixture was employed.
\end{abstract}

Keywords : $\mathrm{Li}_{x} \mathrm{KCa}_{2} \mathrm{Na}_{2} \mathrm{Nb}_{5} \mathrm{O}_{16}$ superconductor compounds; dissolution method ; mixture of HF$\mathrm{HNO}_{3}-\mathrm{H}_{2} \mathrm{SO}_{4} ; \mathrm{ICP}-\mathrm{OES}$.

\section{1 緒 言}

層状ペロブスカイト型ニオブ酸化物 $\mathrm{AB}_{2} \mathrm{Nb}_{3} \mathrm{O}_{10} \quad(\mathrm{~A}=$ = ルカリ金属, $\mathrm{B}=$ アルカリ土類金属) は $\mathrm{NbO}_{6}$ 八面体を $\mathrm{c}$ 軸方向に 3 つ重ねた結晶構造（3枚層）を持ち, Li インタ 一カレーションにより超伝導 $\left(T_{\mathrm{c}}<6 \mathrm{~K}\right)$ を示す ${ }^{1)} . \mathrm{NbO}_{6}$ 八面体を 4 つ積み重ねた 4 枚層構造では $\mathrm{Li}$ インターカレ ーションをしても超伝導を示さない。これは 3 枚層構造 では平坦な $\mathrm{NbO}_{2}$ が存在するが，4枚層構造では平坦な $\mathrm{NbO}_{2}$ 面が存在しないためと考えられる ${ }^{23)}$. そこで, 平坦 な $\mathrm{NbO}_{2}$ 面の存在が予想される $\mathrm{NbO}_{6}$ 八面体を 5 つ重ねた 5 枚層構造を持つ $\mathrm{KCa}_{2} \mathrm{Na}_{2} \mathrm{Nb}_{5} \mathrm{O}_{16}$ に $\mathrm{Li}$ インターカレーシ ヨンを行った $\mathrm{Li}_{x} \mathrm{KCa}_{2} \mathrm{Na}_{2} \mathrm{Nb}_{5} \mathrm{O}_{16}$ が注目されている。

これらの材料の物性測定との関連で欠かせないのが構成

${ }^{1}$ 東北大学金属材料研究所：980-8577 宮城県仙台市青葉区片平 2-1-1
元素の化学分析であるが，これらの組成分析をした例はな い. 一般に酸化物超伝導物質の組成分析は試料を適当な酸 で加熱分解するか, 適当な融剤とともにるつぼ中で加熱融 解することによって試料を溶液化し，その試料溶液を誘導 結合プラズマ発光分光分析 (ICP-OES) で定量する.

この組成分析操作では試料を完全に溶液化できるか否か が大きな問題になる。一般には融剤は硫酸水素カリウムや 二硫酸ナトリウム（ピロ硫酸ナトリウム）などの酸性融剤 が用いられるが，これらの融剤は高純度な試薬が入手でき ないことや，アルカリ金属（ナトリウム，カリウム）を含 んでおり，本実験で対象とした試料のように試料組成とし てナトリウムやカリウムを含有している試料には使用でき ない. ニオブ酸化合物の分解法として硫酸水素アンモニウ ムを融剤に用いた報告 ${ }^{4) 5}$ があるが，この融剤も他の融剂 と同様に高純度な試薬の入手は困難であり，使用には難点 がある。本報告では，焼成して作製した $\mathrm{KCa}_{2} \mathrm{Na}_{2} \mathrm{Nb}_{5} \mathrm{O}_{16}$ 
及び $\mathrm{Li}$ インターカレーションした $\mathrm{Li}_{x} \mathrm{KCa}_{2} \mathrm{Na}_{2} \mathrm{Nb}_{5} \mathrm{O}_{16}$ の両 試料を $\mathrm{HNO}_{3}-\mathrm{HF}_{-} \mathrm{H}_{2} \mathrm{SO}_{4}$ の混酸によって分解し, ICP-OES で定量する方法を報告する。

$$
2 \text { 実験 }
$$

\section{$2 \cdot 1$ 装 置}

マイクロウエーブ加圧分解装置は Berghof 製スピード ウエーブ MWS-3 を使用した。

ICP-OES 装置は Thermo Element 製 IRIS Advantage DUO を使用した.この装置は測光方式としてラジアル測 光とアキシャル測光ができ, 検出器に CID (charged induced device) カメラを用いることで，多波長を同時に 測定できることが特徵である。またプラズマトーチ管にロ ングトーチ管を使用しているので, 従来のトーチ管と比較 して, 発光部における空気巻き达みが少なく, 空気に起因 するバックグラウンドを抑えることができるＩCP-OES 装置の装置条件を Table 1 に示す.

\section{$2 \cdot 2$ 試料及び試薬}

試料の $\mathrm{KCa}_{2} \mathrm{Na}_{2} \mathrm{Nb}_{5} \mathrm{O}_{16}$ は炭酸カリウム，炭酸ナトリウ ム, 炭酸カルシウム及び五酸化ニオブを焼成して作製し た ${ }^{6)} \cdot \mathrm{Li}_{x} \mathrm{KCa}_{2} \mathrm{Na}_{2} \mathrm{Nb}_{5} \mathrm{O}_{16}$ は，焼成した $\mathrm{KCa}_{2} \mathrm{Na}_{2} \mathrm{Nb}_{5} \mathrm{O}_{16}$ を $1.6 \mathrm{M} n$-ブチルリチウムヘキサン溶液に浸して Li インター カレーションしたものである。焼成した $\mathrm{KCa}_{2} \mathrm{Na}_{2} \mathrm{Nb}_{5} \mathrm{O}_{16}$ は薄いベージュ色であるが，Liインターカレーションす ることにより黒色に変色する．この試料は大気中に放置す ると大気中の水分とリチウムが反応して試料表面が白く変 色するので，乾燥したアルゴン雾囲気のグローボックス中 に保存し，分析試料としてのひょう量もグローボックス中 で行った.

ICP-OES に用いる各元素の標準溶液 $(1.00 \mathrm{mg} / \mathrm{ml})$ は 高純度試薬を用いて以下のように調製した。

リチウム標準溶液： $110^{\circ} \mathrm{C}$ で乾燥した炭酸リチウム (99.99\%) $0.5323 \mathrm{~g}$ を $\mathrm{HNO}_{3}(1+1) 4 \mathrm{ml}$ で溶解し, 純水 で $100 \mathrm{ml}$ にした。

カリウム標準溶液： $110^{\circ} \mathrm{C}$ で乾燥した炭酸カリウム (99.99\%) $0.1767 \mathrm{~g}$ を $\mathrm{HNO}_{3}(1+1) 4 \mathrm{ml}$ で溶解し, 純水 で $100 \mathrm{ml}$ にした.

ナトリウム標準溶液: $110^{\circ} \mathrm{C}$ で乾燥した塩化ナトリウム (99.99\%) 0.2542 g を純粋で溶解し, 純水で $100 \mathrm{ml}$ にし た。

カルシウム標準溶液: $110^{\circ} \mathrm{C}$ で乾燥した炭酸カルシウム (99.99\%) 0.2497 g を $\mathrm{HNO}_{3}(1+1) 4 \mathrm{ml}$ で溶解し, 純水 で $100 \mathrm{ml}$ にした。

ニオブ標準溶液：金属ニオブ $(99.995 \%) 100 \mathrm{mg}$ をテ フロンビーカー中で $\mathrm{HF} 5 \mathrm{ml}$ と数滴の $\mathrm{HNO}_{3}$ を加えて溶 解後, $\mathrm{H}_{2} \mathrm{SO}_{4}(1+1) 20 \mathrm{ml}$ を加えて $\mathrm{H}_{2} \mathrm{SO}_{4}$ の白煙が発生
Table 1 Instrument and operating conditions of ICPOES

\begin{tabular}{ll}
\hline Instrument & Thermo Elemental Co. Ltd. \\
& IRIS Advantage DUO \\
Spectrometer & Echelle Type \\
Resolving power & $<0.005 \mathrm{~nm}$ (near $200 \mathrm{~nm})$ \\
& $<0.01 \mathrm{~nm}$ (near $400 \mathrm{~nm})$ \\
& $<0.02 \mathrm{~nm}$ (near $600 \mathrm{~nm})$ \\
Detector & CID \\
RF frequency & $27.12 \mathrm{kHz}$ \\
RF power & $1.15 \mathrm{~kW}$ \\
Argon gas flow & \\
Plasma gas & $151 /$ min \\
Nebulizer gas & 28 psi \\
Auxiliary gas & 0.5 l/min \\
Torch & Long torch \\
Sample uptake & Peristaltic pump \\
Optical view method & Axial or Radial view \\
Integrated time & 30 s (short wavelength region) \\
& 15 s $($ long wavelength region) \\
Spectral lines used & Li II $670.784 \mathrm{~nm}$ \\
& Na I $588.995 \mathrm{~nm}$ \\
& Na I $589.592 \mathrm{~nm}$ \\
& Ca II $183.801 \mathrm{~nm}$ \\
& Ca II $184.006 \mathrm{~nm}$ \\
& Ca II $315.887 \mathrm{~nm}$ \\
& Ca II $317.933 \mathrm{~nm}$ \\
& K I $766.496 \mathrm{~nm}$ \\
& Nb II $309.418 \mathrm{~nm}$ \\
Nb II $313.079 \mathrm{~nm}$ \\
Nb II $316.340 \mathrm{~nm}$ \\
Nb II $319.498 \mathrm{~nm}$ \\
Y II $242.220 \mathrm{~nm}$ (internal standard) \\
Y II $371.030 \mathrm{~nm}$ (internal standard) \\
\hline
\end{tabular}

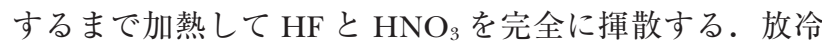
後, 酒石酸 $0.5 \mathrm{~g}$ を加え, あらかじめ過酸化水素水 $(30 \%)$ $2 \mathrm{ml}$ を入た $100 \mathrm{ml}$ メスフラスコに冷却しながら移し， 純水により標線まで希釈する.

イットリウム標準溶液：三酸化二イットリウム (99.99\%) $1.2699 \mathrm{~g}$ を $\mathrm{HNO}_{3}(1+1) 20 \mathrm{ml}$ で溶解し, 純水 で $1000 \mathrm{ml}$ にした.

上記標準溶液は，使用時に所定の濃度に純水で希釈して 使用した。ただし，ニオブ溶液の希釈は加水分解が起きな い上うに $\mathrm{H}_{2} \mathrm{SO}_{4}$ 濃度が $1 \mathrm{M}$ 以上，過酸化水素水 $2 \%$ 以上 共存させるようにした.

$\mathrm{HF}, \mathrm{HNO}_{3}, \mathrm{H}_{2} \mathrm{SO}_{4}$, 過酸化水素水及び酒石酸は市販の 特級試薬を使用した。

\section{3 結果及び考察}

試料の分解法の検討は焼成した $\mathrm{KCa}_{2} \mathrm{Na}_{2} \mathrm{Nb}_{5} \mathrm{O}_{16}$ 及び $\mathrm{Li}$ インターカレーションした $\mathrm{Li}_{x} \mathrm{KCa}_{2} \mathrm{Na}_{2} \mathrm{Nb}_{5} \mathrm{O}_{16}$ の両試料を 用いて行った。

\section{$3 \cdot 1$ 酸加熱分解法}

試料 $20 \mathrm{mg}$ を白金血又はテフロンビーカー中に入れ， 
酸を加えて熱板上で加熱し，試料の分解の可否を検討し た. 試料にはニオブを含有しているので，加水分解が起き ないように酸の濃度を考慮して以下のような実験を行っ た.

$\mathbf{3} \cdot \mathbf{1} \cdot \mathbf{1} \mathrm{HF}_{-} \mathrm{HNO}_{3}$ の混酸による分解 $\mathrm{HF} 10 \mathrm{ml}$ に数 滴の $\mathrm{HNO}_{3}$ を加えて加熱分解した。 $\mathrm{KCa}_{2} \mathrm{Na}_{2} \mathrm{Nb}_{5} \mathrm{O}_{16}$ 試料 は全く分解しなかった。 $\mathrm{Li}_{x} \mathrm{KCa}_{2} \mathrm{Na}_{2} \mathrm{Nb}_{5} \mathrm{O}_{16}$ 試料は黒色で あるが, $\mathrm{HF}^{-\mathrm{HNO}_{3}}$ の混酸による加熱でベージュ色に変色 するが, 分解はしなかった. $\mathrm{HNO}_{3}$ 量を数滴から $5 \mathrm{ml}$ ま で増やして加熱した実験や，加熱時間を 30 分から 15 時 間まで変えた実験でも試料は分解しなかった。

$3 \cdot 1 \cdot 2 \mathrm{HF}-\mathrm{HNO}_{3}-\mathrm{H}_{2} \mathrm{SO}_{4}$ の混酸による分解 $3 \cdot 1 \cdot 1$

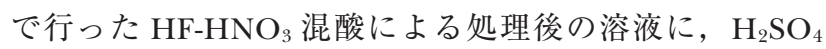
$(1+1) 10 \mathrm{ml}$ を添加し加熱すると試料は容易に分解した. また別に採取した試料に $\mathrm{HF} 10 \mathrm{ml}, \mathrm{HNO}_{3} 2 \mathrm{ml}, \mathrm{H}_{2} \mathrm{SO}_{4}$ $(1+1) 10 \mathrm{ml}$ を同時に添加して加熱しても試料は容易に 分解した。 これは $\mathrm{H}_{2} \mathrm{SO}_{4}$ の添加によって分解温度が高く できたことによると考えられる.

$3 \cdot 1 \cdot 3 \quad \mathrm{H}_{2} \mathrm{SO}_{4}$ による分解 $3 \cdot 1 \cdot 2$ の実験結果から $\mathrm{H}_{2} \mathrm{SO}_{4}$ の添加が有効であることが分かったので, $\mathrm{H}_{2} \mathrm{SO}_{4}$ 単独での分解を行った. $\mathrm{H}_{2} \mathrm{SO}_{4}(1+1) 10 \mathrm{ml}$ を添加し, $\mathrm{H}_{2} \mathrm{SO}_{4}$ の白煙が出るまで加熱したが試料は分解しなかっ た.

以上の実験結果から，試料は $\mathrm{HF}, \mathrm{HNO}_{3}$ 及び $\mathrm{H}_{2} \mathrm{SO}_{4}$ の 3 つの酸が共存している状態で加熱すると分解することが 分かった.

\section{$3 \cdot 2$ マイクロウエーブ加圧分解法}

近年, 分析試料の溶液化にマイクロマイクロウエーブを 利用した加圧分解法多く利用されるようになり, 試料溶液 調製の時間短縮が図られているので，本報告の試料につい ても以下の実験を行った。

試料 $20 \mathrm{mg}$ をテフロン製分解容器に入れ, 酸を添加後 密閉してマイクロウエーブ加圧分解装置にセットする. 加 熱はマイクロウエーブ加圧分解装置に Table 2 に示す温度 プログラムを設定し, それに従って行った. 放冷後, 装置 からテフロン製容器を取り出し, 更に十分に水冷してから 容器のふたをあけて試料の分解の可否を検討した。

3・2・1 $\mathrm{HF}^{-\mathrm{HNO}_{3}}$ の混酸による分解 $\mathrm{HF} 7 \mathrm{ml}$ と $\mathrm{HNO}_{3} 3.5 \mathrm{ml}$ を添加してマイクロウエーブ加圧分解装置で 加熱したが, 試料は全く分解しなかった。この溶液と未溶 解試料を白金皿に移し, $\mathrm{H}_{2} \mathrm{SO}_{4}(1+1) 10 \mathrm{ml}$ を添加後加 熱すると試料は分解した.

3・2・2 $\mathrm{HF}-\mathrm{HNO}_{3}-\mathrm{H}_{2} \mathrm{SO}_{4}$ の混酸による分解 HF 5 $\mathrm{ml}, \mathrm{HNO}_{3} 2.5 \mathrm{ml}$ 及び $\mathrm{H}_{2} \mathrm{SO}_{4} 5 \mathrm{ml}$ を添加してマイクロウ エーブ加圧分解装置で加熱した結果, 試料は完全に分解し た.
Table 2 Temperature program for microwave-assisted acid dissolution method

\begin{tabular}{crrrr}
\hline Stage & 1 & \multicolumn{1}{c}{2} & \multicolumn{1}{c}{3} & \multicolumn{1}{c}{4} \\
\hline Temperature $/{ }^{\circ} \mathrm{C}$ & 120 & 170 & 100 & 100 \\
Ramp time $/ \mathrm{min}$ & 10 & 5 & 1 & 1 \\
Hold time $/ \mathrm{min}$ & 15 & 30 & 0 & 0 \\
\hline
\end{tabular}

3・2・3 $\mathrm{H}_{2} \mathrm{SO}_{4}$ による分解 $\mathrm{H}_{2} \mathrm{SO}_{4}$ のみでのマイクロ ウエーブ加圧分解では試料は分解しなかった.

これらの実験結果から，マイクロウエーブ加圧分解法で も酸加熱分解法と同様に $\mathrm{HF}, \mathrm{HNO}_{3}$ 及び $\mathrm{H}_{2} \mathrm{SO}_{4}$ の 3 つの 酸が共存している状態で加熱すると試料は分解することが 分かった。しかし，マイクロウエーブ加圧分解法による利 点は特に認められなかった。

以上の分解法に関する実験結果から, 試料の分解は HF, $\mathrm{HNO}_{3}$ 及び $\mathrm{H}_{2} \mathrm{SO}_{4}$ の 3 つの酸の混合溶液を用いて加熱分 解法で行うことにした。

\section{$3 \cdot 3$ 定量操作}

試料分解法の実験結果から以下のような分析方法を確立 した。

試料 $100 \mathrm{mg}$ をひょう量し, 白金血又はテフロンビーカ 一に移す. $\mathrm{HF} 10 \mathrm{ml}, \mathrm{HNO}_{3} 3 \mathrm{ml}$ 及び $\mathrm{H}_{2} \mathrm{SO}_{4}(1+1) 15$ $\mathrm{ml}$ を添加し熱板上で加熱分解する。使用した ICP-OES 装 置は耐 HF 仕様になっておらず，試料溶液中の HF を完全 に除去しなければならないので，試料の分解後， $\mathrm{H}_{2} \mathrm{SO}_{4}$ の白煙が発生するまで加熱を続けて $\mathrm{HF}$ と $\mathrm{HNO}_{3}$ を完全 に揮散させる．放冷後，二オブの加水分解を抑えるために 酒石酸 $0.25 \mathrm{~g}$ を加え，あらかじめ過酸化水素水 (30\%) 1 $\mathrm{ml}$ を入れた $100 \mathrm{ml}$ メスフラスコに溶液を移す。更に白金 皿中の残りの溶液に酒石酸 $0.25 \mathrm{~g}$ を加えて, 純水で洗い ながら容器中の試料溶液を完全にメスフラスコに移す。こ のとき $\mathrm{H}_{2} \mathrm{SO}_{4}$ 溶液の希釈に伴う発熱によってニオブが加 水分解するのを抑えるため，試料溶液が発熱しないように 水冷しながら希釈する.

ICP-OES 定量のために内標準元素としてイットリウム 溶液（100 $\mu \mathrm{g} \mathrm{Y} / \mathrm{ml} ）$ を正確に $10 \mathrm{ml}$ 添加後，純水で 100 $\mathrm{ml}$ にする（試料溶液 A)。試料溶液 $\mathrm{A}$ から, 正確に $20 \mathrm{ml}$ を分取して $100 \mathrm{ml}$ メスフラスコに入れる. $\mathrm{H}_{2} \mathrm{SO}_{4}(1+1)$ $12 \mathrm{ml}$, 過酸化水素水 $(30 \%) 0.8 \mathrm{ml}$, 酒石酸 $0.4 \mathrm{~g}$ 及び内 標準元素としてイットリウム溶液 $(100 \mu \mathrm{g} \mathrm{Y} / \mathrm{ml})$ を正確 に $8 \mathrm{ml}$ 添加後, 純水で $100 \mathrm{ml}$ にする（試料溶液 B).

試料溶液 $\mathrm{A}$ を用いてリチウム, ナトリウム及びカルシ ウムを，試料溶液 B を用いてニオブとカリウムをそれぞ れ ICP-OES で定量する。試料溶液 A 中のリチウム，ナト リウム及びカルシウム定量のための検量線溶液作製ではニ 
オブとカリウムを, 試料溶液 B 中のニオブとカリウム定 量のための検量線溶液作製ではナトリウムとカルシウムを それぞれ試料溶液と同濃度になるように添加してマトリッ クスマッチングした検量線溶液を調製した。

ICP-OES 定量ではすべてイットリウムを内標準として 測定した。本実験で使用した ICP-OES 装置は短波長領域 と長波長領域が時間差を持って測定されるため（打打よそ $280 \mathrm{~nm}$ 付近で分ける), 内標準線も短波長領域と長波長 領域のそれぞれの測定線を使用した。測定に使用した波長 はTable 1 に示した.

適当な発光強度が得られるように, カリウム, ニオブ, リチウム，ナトリウム及びカルシウムの長波長領域はラジ アル測光を, カルシウムの短波長領域はアキシャル測光に より測定した。測定波長はリチウムとカリウムは 1 本の 測定線を使用したが，ナトリウム，カルシウム及びニオブ は複数の測定線を使用し, 分析值は各測定線で得られた值 の平均值を定量值とした.

ICP-OES 測定では基準溶液を各試料溶液の測定前後に 定量してプラズマの変動, 試料溶液導入量の変化等に起因 する定量値の変動を補正した。

\section{$3 \cdot 4$ 定量結果}

$3 \cdot 3$ の定量操作に従って分析した定量結果を Table 3 に 示す。試料番号順に $n$-ブチルリチウムへキサン溶液に浸 して Li インターカレーションを行った時間が長くなって いる．定量值は浸せき時間にかかわらず 4 つの試料とも 組成はほぼ同じであった。これは浸せき時間が 17 日では
Table 3 Analytical results

\begin{tabular}{|c|c|c|c|c|c|c|}
\hline \multirow{2}{*}{ Specimen } & \multirow{2}{*}{$\begin{array}{l}\text { Time for } \mathrm{Li}- \\
\text { intercalation } / \mathrm{d}\end{array}$} & \multicolumn{5}{|c|}{ Found/mass $\%$} \\
\hline & & $\mathrm{Li}$ & $\mathrm{K}$ & $\mathrm{Ca}$ & $\mathrm{Na}$ & $\mathrm{Nb}$ \\
\hline 1 & 17 & 0.471 & 2.47 & 8.99 & 5.68 & 51.9 \\
\hline 2 & 22 & 0.447 & 2.58 & 8.70 & 5.72 & 52.1 \\
\hline 3 & 29 & 0.426 & 2.58 & 9.26 & 5.72 & 52.0 \\
\hline 4 & 38 & 0.488 & 2.58 & 9.12 & 5.71 & 51.6 \\
\hline
\end{tabular}

リチウムが飽和しているか，インターカレーションされた リチウムの他に試料表面に吸着したリチウムも定量された ためと考えられる。得られた定量值（重量％）からモル比 に換算すると打打よそ $\mathrm{Li}_{0.6} \mathrm{~K}_{0.6} \mathrm{Ca}_{2.0} \mathrm{Na}_{2.3} \mathrm{Nb}_{5.0} \mathrm{O}$ 落 となった。

本報告で使用した $\mathrm{Li}_{x} \mathrm{KCa}_{2} \mathrm{Na}_{2} \mathrm{Nb}_{5} \mathrm{O}_{16}$ 試料は, 東北大学大学院 工学研究科応用物理学専攻低温 - 超伝導物理学分野 小池洋二教 授, 加藤雅恒助教授, 同大学院院生梶田徹也氏から提供されたも のである。ここに感謝の意を表す。

\section{文献}

1) Y. Takano, H. Taketomi, H. Tsurumi, T. Yamadaya, N. Mori : Physica B, 237, 68 (1997).

2) Nagai, A. Abe, M. Kato, Y. Koike, M. Makihana: Solid. State Ionics, 151, 265 (2002).

3) M. Kato, A. Inoue, I. Nagai, M. Kakihana, A. W. Sleight, Y. Koike: Physica C, 388-389, 445 (2003).

4) T. Ashino, K. Takada: Anal. Sci., 9, 737 (1993).

5) T. Ashino, K. Makabe, K. Takada: Fresenius J. Anal. Chem., 349, 772 (1994).

6) 梶田徹也, 加藤雅恒, 小池洋二: 応用物理東北支部 第 57 回学術講演会講演予稿集, p. 178 (2002). 